University of Nebraska - Lincoln

DigitalCommons@University of Nebraska - Lincoln

Publications from USDA-ARS / UNL Faculty

U.S. Department of Agriculture: Agricultural

Research Service, Lincoln, Nebraska

October 2007

\title{
Engineering, nutrient removal, and feedstock conversion evaluations of four corn stover harvest scenarios
}

\author{
Reed L. Hoskinson \\ Idaho National Laboratory \\ Douglas L. Karlen \\ USDA-ARS, National Soil Tilth Luhorutory, Ames, IA, doug.karlen@ars.usda.gov \\ Stuart J. Birrell \\ lowa State University, Agricultural and Biosysterns Engineering Department, Ames, IA, \\ sbirrell@iastate.edu \\ Corey W. Radtke \\ Idaho National Laboratory, Idaho Falls, ID \\ Wally Wilhelm \\ University of Nebraska-Lincoln, wally.wilhelm@ars.usda.gov
}

Follow this and additional works at: https://digitalcommons.unl.edu/usdaarsfacpub

Part of the Agricultural Science Commons

Hoskinson, Reed L.; Karlen, Douglas L.; Birrell, Stuart J.; Radtke, Corey W.; and Wilhelm, Wally, "Engineering, nutrient removal, and feedstock conversion evaluations of four corn stover harvest scenarios" (2007). Publications from USDA-ARS / UNL Faculty. 70.

https://digitalcommons.unl.edu/usdaarsfacpub/70

This Article is brought to you for free and open access by the U.S. Department of Agriculture: Agricultural Research Service, Lincoln, Nebraska at DigitalCommons@University of Nebraska - Lincoln. It has been accepted for inclusion in Publications from USDA-ARS / UNL Faculty by an authorized administrator of DigitalCommons@University of Nebraska - Lincoln. 


\title{
Engineering, nutrient removal, and feedstock conversion evaluations of four corn stover harvest scenarios
}

\author{
Reed L. Hoskinson ${ }^{\mathrm{a}}$, Douglas L. Karlen ${ }^{\mathrm{b}, *}$, Stuart J. Birrell ${ }^{\mathrm{c}}$, \\ Corey W. Radtke ${ }^{\mathrm{a}}$, W.W. Wilhelm ${ }^{\mathrm{d}}$ \\ "Idaho National Laboratory, P.O Box 1625, Idaho Falls, ID 83415-2210, USA \\ ${ }^{\mathrm{b}}$ USDA-ARS, National Soil Tilth Laboratory, Ames, IA 50011-3120, USA \\ 'Iowa State University, Agricultural and Biosystems Engineering Department, Ames, IA 50011, USA \\ ${ }^{\mathrm{a}}$ USDA-ARS, Soil and Water Conservation Research Unit, Lincoln, NE 68583-0934, USA
}

Received 25 April 2006; received in revised form 21 June 2006; accepted 30 July 2006

Available online 1 November 2006

\begin{abstract}
Crop residue has been identified as a near-term source of biomass for renewable fuel, heat, power, chemicals and other bio-materials. A prototype one-pass harvest system was used to collect residue samples from a corn (Zea mays L.) field near Ames, IA. Four harvest scenarios (low cut, high-cut top, high-cut bottom, and normal cut) were evaluated and are expressed as collected stover harvest indices (CSHI). High-cut top and high-cut bottom samples were obtained from the same plot in separate operations. Chemical composition, dilute acid pretreatment response, ethanol conversion yield and efficiency, and thermochemical conversion for each scenario were determined. Mean grain yield in this study $\left(10.1 \mathrm{Mg} \mathrm{ha}^{-1}\right.$ dry weight) was representative of the average yield $\left(10.0 \mathrm{Mg}^{-1}\right)$ for the area (Story County, IA) and year (2005). The four harvest scenarios removed 6.7, 4.9, 1.7, and $5.1 \mathrm{Mgha}^{-1}$ of dry matter, respectively, or 0.60 for low cut, 0.66 for normal cut, and 0.61 for the total high-cut (top + bottom) scenarios when expressed as CSHI values. The macronutrient replacement value for the normal harvest scenario was $\$ 57.36 \mathrm{ha}^{-1}$ or $\$ 11.27 \mathrm{Mg}^{-1}$. Harvesting stalk bottoms increased stover water content, risk of combine damage, estimated transportation costs, and left insufficient soil cover, while also producing a problematic feedstock. These preliminary results indicate harvesting stover (including the cobs) at a height of approximately $40 \mathrm{~cm}$ would be best for farmers and ethanol producers because of faster harvest speed and higher quality ethanol feedstock.
\end{abstract}

(C) 2006 Elsevier Ltd. All rights reserved.

Keywords: Biomass; Zea mays; Crop residue; Bioenergy; Ethanol; Simultaneous saccharification and fermentation (SSF); Thermochemical conversion

\section{Introduction}

The US Department of Energy (DOE), Office of Biomass Program (OBP) plans to accelerate the use of agricultural residue as a near-term source of biomass for renewable fuel, heat, power, chemicals and other biomaterials. To implement this vision [1], the OBP is supporting development of science and technologies that

\footnotetext{
${ }^{*}$ Corresponding author. Tel.: + 15152943336 ; fax: + 15152948125 .

E-mail addresses: rhoskinson $($ cableone.net (R.L. Hoskinson), karlen@nstl.gov (D.L. Karlen), sbirrell@iastate.edu (S.J. Birrell), corey.radtke@inl.gov (C.W. Radtke),wwilhelm1@unl.edu (W.W. Wilhelm).
}

will help establish biomass as a significant source of environmentally sound, sustainable and renewable fuels, heat, power, chemicals and materials [2]. These efforts will complement commercial ventures [3] and are expected to make important contributions to US energy security while supporting and enhancing rural economic development and environmental quality [4]. The OBP plan is to work through existing and new partnerships toward a major solicitation for a biomass-based ethanol plant in $2008[5]$.

Graham et al. [6] estimated the total corn stover production in the Northern Iowa/Southern Minnesota region at $7.61 \mathrm{Mgha}^{-1}$ and that about two-thirds $\left(5.16 \mathrm{Mg} \mathrm{ha}^{-1}\right)$ could be collected in a sustainable manner. 
Though Graham et al. [6] suggest a portion of the stover produced should be left in these Corn Belt fields, they give no information on what portion of the plant would be most advantageous for biomass ethanol production or which part or parts of the plant would be best to leave in the field. An additional question of how to most efficiently collect stover has not been addressed.

Stover is composed of several identifiable components, all with different functions in the plant and different characteristics. Hanway [7] reported that cobs represented about $9 \%$ of the above ground biomass at physiological maturity. Overall, husks, shanks, silks and cobs account for $30 \%$ of the stover mass, while stalks, tassels, leaf blades and leaf sheaths account for the remaining $70 \%$. Pordesimo et al. [8] reported $15 \%$ of the stover dry mass is cob and that stalks (plus leaf sheaths and tassel), leaf blades, and husks (plus shank) accounted for $51 \%, 21 \%$, and $13 \%$ of the stover, respectively. These differences may reflect harvest method and/or cultivar, but including cobs as part of the collected stover fraction is important and would partially address transportation and storage concerns because cobs are the most dense stover component. Crofcheck and Montross [9] reported greater conversion efficiency, release of glucose, from both native (untreated) and $\mathrm{NaOH}$-pretreated cobs than other stover components (leaves, stalks, and husks).

With regard to sustainability of the soil resources, removing stalks very close to the soil surface will result in less surface residue cover, exacerbate the potential wind and water erosion [10-12], accelerate the decline in soil organic carbon levels $[13,14]$, and potentially reduce future crop yields [15]. More detailed discussions of potential impacts of stover removal on future productivity and soil quality are presented by Wilhelm et al. [16], Wilts et al. [17], and Kim and Dale [18]. Understanding this component of biomass removal, including the additional plant nutrients that will be removed and have to be replaced, is very important for the long-term success of the bio-energy system.

To minimize the effect of residue removal on soil resources, Crofcheck and Montross [9] suggested collecting only the fraction of corn stover with the greatest glucose potential (i.e. cobs, leaves, and husks) and leaving the remaining stover in the field for soil erosion control and to help sustain soil organic carbon reserves. Currently, that fraction ( $\sim 30 \%$ of stover mass) passes through the combine and falls to the ground. Development of a harvest system to capture this material is thus an engineering challenge that will make biomass recovery from corn more efficient and profitable.

Our assessment based on 2005 field-plot data examines (i) the engineering challenges associated with harvesting corn stover, (ii) the amount of plant nutrients removed with the stover and the potential impact of stover removal on future crop production and soil quality indicators, and (iii) the potential ethanol production from the various stover fractions.

\section{Materials and methods}

\subsection{Stover collection and analyses}

Corn stover samples were collected from plots established within a general production site at the ISU Agronomy and Agricultural Engineering Farm near Ames, IA $\left(42^{\circ} 2^{\prime} \mathrm{N} 93^{\circ} 48^{\prime} \mathrm{W}\right)$. The corn hybrid was 'Fontenell 5393', grown following a 2004 soybean [Glycine $\max (\mathrm{L}$.) Merr.] crop and fertilized with $\sim 170 \mathrm{~kg} \mathrm{Nha}^{-1}$. Four stover harvest scenarios (low cut, high-cut top, high-cut bottom, and normal cut) were evaluated approximately 30 days after physiologic maturity (growth stage R6) using an experimental harvesting system that consisted of a John Deere 9750 STS combine, a 6-row John Deere 653A row crop header with a prototype corn reel, and a standard John Deere rear chopper (Deere \& Co, Moline, $\mathrm{IL}^{\mathrm{l}}$ ) (Fig. 1).

The four harvest scenarios were achieved by varying the cutting height of the combine head. The low cut left approximately $10 \mathrm{~cm}$ of stubble and a minimum amount of leaf tissue in the field (Fig. 2). All other material passed through the combine with the grain being separated from the stover and cobs. For the normal cut, the header was positioned about midway between the base of the ears and the soil surface. This left approximately $40 \mathrm{~cm}$ of stubble plus the leaves that had been attached below the cutting height (Fig. 2). High-cut top samples were obtained by cutting the plants just below the ears so that only the ears and plant parts above them entered the combine. This resulted in a stubble height of approximately $75 \mathrm{~cm}$ (Fig. 3). The high-cut bottom samples were collected in a subsequent operation by making a second pass across the highcut top transects with the header set as it had been for the low cut treatment (i.e. stubble height of $\sim 10 \mathrm{~cm}$ ).

All cobs and stover material above the header's rotary knives were conveyed into the combine threshing system through the feederhouse. Stover discharged from the rear chopper was directed into a Gehl forage blower (Model FB85, Gehl, West Bend, WI) driven by a $48 \mathrm{~kW}$, Wisconsin V-4 air-cooled engine (Model V465D, Wisconsin Motors, LLC, Memphis, TN) attached to the rear of the combine. Stover passing through the forage blower was collected in a forage wagon equipped with a Weigh-Tronix weight measurement system (Model 1000R, Weigh-Tronix, Fairmont, $\mathrm{MN}$ ) to record the mass of stover collected for each harvest transect. In addition, the mass of grain for each harvest transect was recorded using a Parker 500 Grain wagon equipped with a similar Weigh-Tronix measurement system (Model 1015, Weigh-Tronix, Fairmont, MN).

\footnotetext{
${ }^{1}$ References herein to any specific commercial product, process, or service by trade name, trademark, manufacturer, or otherwise, does not necessarily constitute or imply its endorsement, recommendation, or favoring by the U.S. Government, any agency there of, or any company affiliated with the Idaho National Laboratory or Iowa State University.
} 


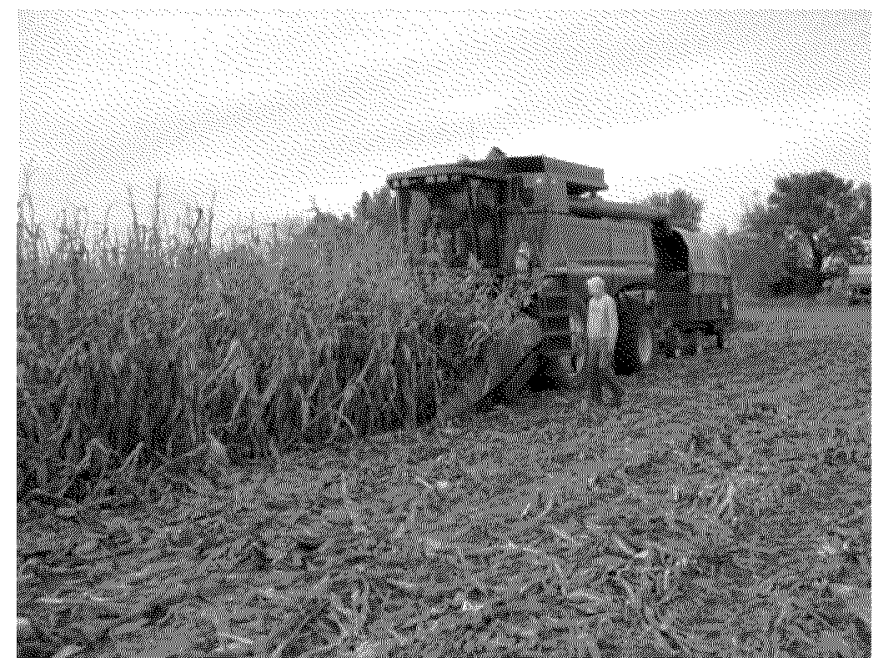

Fig. 1. The low cut stover collection.

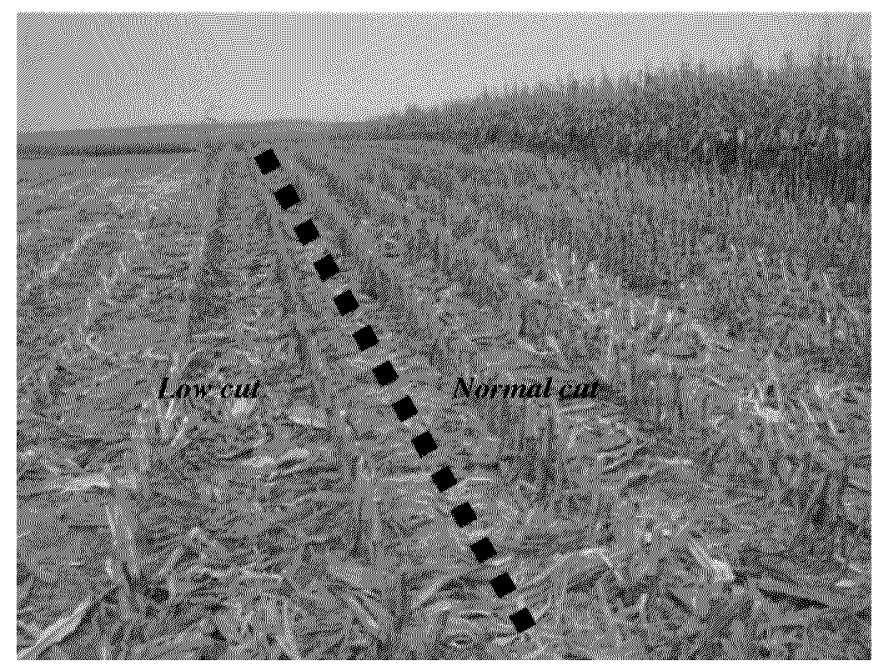

Fig. 2. Showing the low cut area (left side) and the normal cut area right side).

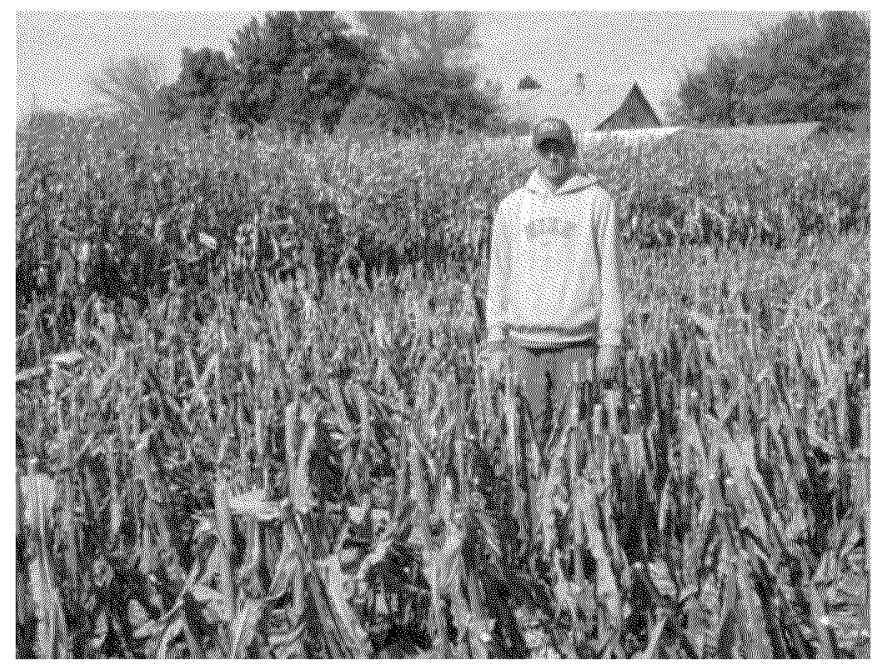

Fig. 3. Reference height of stubble remaining after high-cut top stover collection.
The stover samples from all four harvest scenarios were analyzed for water content, macro- and micro-nutrient concentrations, chemical composition influencing ethanol production, dilute acid pretreatment response, and ethanol conversion efficiency. Subsamples were also sent to a commercial laboratory to determine several thermochemical conversion parameters: ultimate, proximate, chlorine, ash, chlorine and carbon dioxide in ash, as well as oxidating and reducing fusion temperatures.

\subsection{Stover mutrient removal}

Plant nutrient removal and water content were determined on stover samples dried for $48 \mathrm{~h}$ in a forced-draft oven at $60^{\circ} \mathrm{C}$. Dried samples were ground to pass a $0.5 \mathrm{~mm}$ stainless-steel screen and a subsample was digested in sulfuric acid and $30 \%$ hydrogen peroxide [19]. Digests were analyzed for total $\mathrm{P}, \mathrm{K}, \mathrm{Ca}, \mathrm{Mg}, \mathrm{Cu}, \mathrm{Fe}, \mathrm{Mn}$, and $\mathrm{Zn}$ content via inductively coupled plasma (ICP) spectroscopy. Another subsample of the dried, ground stover was analyzed for total $\mathrm{C}$ and $\mathrm{N}$ via dry combustion. Macroand micro-nutrient removal was calculated using the measured nutrient concentrations and the amount of biomass corrected for water content to a dry-weight basis. A third set of stover samples were analyzed for their chemical constituents for relevance as a feedstock for biochemical conversion to ethanol. A Foss 6500 NIR instrument, calibrated using the NREL corn stover calibration model [20], was used to estimate the compositional characteristics.

\subsection{Stover conversion}

A reduced-severity dilute sulfuric acid pretreatment screening method was used to estimate the potential for using cheaper industrial ethanol production methods. The samples were ground to pass a $2-\mathrm{mm}$ stainless-steel screen with a knife mill, dried overnight at $80^{\circ} \mathrm{C}$, allowed to cool, and digested with $0.8 \%$ sulfuric acid $(\mathrm{w} / \mathrm{w})$. A $2.5 \mathrm{~g}$ biomass subsample was added to $75 \mathrm{~mL}$ of acid, allowed to incubate at room temperature for about $2 \mathrm{~h}$ to enable the acid to permeate the biomass, and then autoclaved at $121^{\circ} \mathrm{C}$, $145 \mathrm{kPa}$ for $30 \mathrm{~min}$. After cooling, the wet biomass was vacuum filtered through Gooch crucibles with glass filters, rinsing with a minimal amount of deionized water to recover all the biomass. Liquid recovered from the wet biomass and the rinsate were combined and brought to $100 \mathrm{~mL}$ with deionized water (this liquid is called the pretreatment liquid in the remainder of the paper). The biomass was washed with deionized water for $3-4 \mathrm{~min}$ to remove residual $\mathrm{H}_{2} \mathrm{SO}_{4}$, which can inhibit fermentation, weighed and stored for later use in simultaneous saccharification and fermentation (SSF) reactions.

Oligomers in a $2.95 \mathrm{~mL}$ aliquot of the pretreatment liquid were hydrolyzed with $0.05 \mathrm{~mL}$ of concentrated sulfuric acid. This mixture was autoclaved at $121^{\circ} \mathrm{C}$, $145 \mathrm{kPa}$ for $20 \mathrm{~min}$. The hydrolyzed pretreatment liquid 
( $2 \mathrm{ml}$ ) was then neutralized with $1-3 \mathrm{~g}$ of lead carbonate, by intermittent vortexing, until the $\mathrm{pH}$ was 4.5 or above. Samples were then diluted $10 \times$ with deionized water, filtered, and analyzed on an HPLC for lignocellulosic sugars as previously described [21].

The SSF analysis was conducted aseptically in $60 \mathrm{~mL}$ serum vials as previously described $[22,23]$. All solutions were sterilized by autoclaving for $30 \mathrm{~min}$ at $121^{\circ} \mathrm{C}$ and $145 \mathrm{kPa}$, and/or by filter sterilization $(0.2 \mu \mathrm{m})$ prior to use. The samples plus a series of controls without corn stover were analyzed in quadruplicate. Each vial received $1.0 \mathrm{~g}$ of dry biomass sample or an equivalent of pretreated sample (corrected for water content to provide $1 \mathrm{~g}$ of dry material). Water was added to achieve a final volume of $30 \mathrm{~mL}$. The vial headspace was purged for 2 min with oxygen-scrubbed ultra high purity nitrogen, and sealed with butyl stoppers and aluminum closures. Vials were autoclaved at $121^{\circ} \mathrm{C}$ and $145 \mathrm{kPa}$ for $30 \mathrm{~min}$. Once cooled to room temperature, $5 \mathrm{~mL}$ of enzyme cocktail was added. The cocktail contained $1.36 \mathrm{~mL}$ of $1 \mathrm{M}$ citric acid buffer, $\mathrm{pH} 4.4 ; 2.7 \mathrm{~mL}$ of $10 \times$ yeast-peptone stock solution $(100 \mathrm{~g} / \mathrm{L}$ yeast extract, $200 \mathrm{~g} / \mathrm{L}$ peptone); and $1 \mathrm{~mL}$ of diluted Spezyme CP (Genencor; Palo Alto, CA) diluted to a final concentration of $0.03 \mathrm{~mL} /$ $30 \mathrm{~mL}$ reaction vial, in phosphate buffered saline (PBS, $11.8 \mathrm{mM}$ phosphate buffer, pH 7; $200 \mathrm{mM} \mathrm{NaCl}, 27 \mathrm{mM}$ $\mathrm{KCl}$ ) solution. Finally, $1.0 \mathrm{~mL}$ of yeast preparation was aseptically added to each vial. This gave a final OD600 of 0.5 for each experimental vial. The yeast was prepared by inoculating one colony forming unit (CFU) of Saccharomyces cerevisiae NRRL Y-2034 in a $300 \mathrm{~mL}$ liquid yeast peptone glucose solution $(Y P G ; 10 \mathrm{~g} / \mathrm{L}$ yeast extract, $20 \mathrm{~g} / \mathrm{L}$ peptone, $50 \mathrm{~g} / \mathrm{L}$ glucose). The culture incubated aerobically overnight $(19-22 \mathrm{~h})$ at $30^{\circ} \mathrm{C}$ rotating at $175 \mathrm{rpm}$. It was then pelleted by centrifugation and washed once with PBS buffer. The washed yeast pellet was resuspended in PBS to an OD600 of 15. Ethanol production was quantified on days $1,3,5$, and 7 by injecting $200 \mu \mathrm{L}$ of the headspace gas into a gas chromatograph with a flame ionization detector (GC-FID). Standards were prepared using aqueous concentrations of ethanol. Ethanol concentrations were normalized to the theoretical production of $0.51 \mathrm{~g}$ ethanol per $1.0 \mathrm{~g}$ of $\mathrm{C} 6$ sugars for graphical presentation and statistical analyses [23].

\subsection{Thermochemical conversion of stover}

A third set of stover samples was tested for thermochemical conversion parameters by Hazen Research, Inc. in Golden, CO where they used American Society for Testing and Materials (ASTM) Standards. The analyses included proximate analyses; ash by ASTM D3174 modified $\left(600^{\circ} \mathrm{C}\right)$, volatiles using ASTM D3175; ultimate analyses using ASTM D5373, sulfur by ASTM D4239, and chlorine by ASTM D2361; and heating values using ASTM D5865, from which other parameters were calculated. Ash chemical composition was determined using ASTM D2795 modified $\left(600^{\circ} \mathrm{C}\right)$, and ash fusion temperatures were estimated using ASTM D1857.

\section{Results and discussion}

\subsection{Grain yield}

Corn grain yield (Table 1) compared favorably with the $11.7 \mathrm{Mg} \mathrm{ha}^{-1}$ average $\left(150 \mathrm{~g} \mathrm{~kg}^{-1}\right.$ water content) reported for 2005 in Story County, IA by the National Agricultural Statistics Service (NASS) [24]. Having a geographically representative grain yield was important because the NASS does not report stover yields. Consequently, many investigators have estimated crop residue production based on harvest indices $[\mathrm{HI}=$ grain mass $/$ (grain mass + stover mass)] and grain yield. Use of $\mathrm{HI}$ and grain yield to compute potential stover yield is bolstered by the fact that for corn, HI varies over a relatively narrow range (0.48-0.53) [25]. Linden et al. [26] reported that their HI (0.56) did not vary with time (13 yr) or among treatments (including tillage intensity, $\mathrm{N}$ application rate, and stover removal). Tollenaar [27] reported that harvest index differed very little among several era hybrids when grown at their optimum plant population in Ontario. Harvest index and other ratios of grain and stover have been employed to estimate source carbon from corn residues, roots, and rhizodeposits as well as stover yield $[28,29]$.

It should be noted, however, that $\mathrm{HI}$ is a precise term used by plant scientists to describe the partitioning of dry matter. To be calculated accurately and conform to the definition, all above ground mass must be included in the

Table 1

Grain and stover yields for the four harvest scenarios

\begin{tabular}{|c|c|c|c|c|c|c|}
\hline \multirow[t]{2}{*}{ Harvest scenario } & \multicolumn{3}{|l|}{ Grain } & \multicolumn{3}{|l|}{ Stover } \\
\hline & Water $\left(\mathrm{mgg}^{-1}\right)$ & $\mathrm{Wet}^{\mathrm{b}}\left(\mathrm{Mgha}^{-1}\right)$ & Dry & Water $\left(\mathrm{mg} \mathrm{g}^{-1}\right)$ & Wet $\left(\mathrm{Mgha}^{-1}\right)$ & Dry \\
\hline High-cut top & 112 & 11.83 & 10.47 & 196 & 6.05 & 4.86 \\
\hline High-cut bottom ${ }^{a}$ & - & - & - & 639 & 4.75 & 1.71 \\
\hline Low cut & 121 & 11.41 & 10.03 & 338 & 10.10 & 6.68 \\
\hline Normal cut & 118 & 11.04 & 9.74 & 237 & 6.67 & 5.09 \\
\hline
\end{tabular}

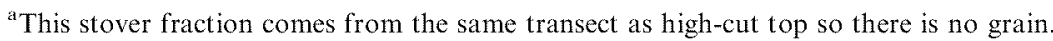

${ }^{b}$ Wet corn grain is the harvest weight adjusted for a water content of $150 \mathrm{~g} \mathrm{~kg}^{-1}$. 
denominator. Therefore, to avoid confusion with other references to HI, we defined an alternative parameter, collected stover harvest index $(\mathrm{CSHI})$ where: $\mathrm{CSHI}=$ grain mass/(grain+collected stover). This was done because even for the low cut harvest scenario, a portion of the corn stover was left in the field. The CSHI is a more accurate representation of the amount of collectable stover produced by crops with specific grain yield. The CSHI values were $0.60,0.66$, and 0.61 for the low, normal, and total high-cut (top + bottom), respectively. Though these values were greater than the $0.5 \mathrm{HI}$ widely used in the literature $[25,26,29]$, we suggest they are more realistic for computing the amount of stover (including cobs) that can be collected with a one pass mechanical harvesting system.

\subsection{Stover collection}

Stover yield, as expected, was greatest for the low-cut scenario $\left(\sim 6.7 \mathrm{Mg} \mathrm{ha}^{-1}\right)$ and for the total high-cut (top + bottom) $\left(\sim 6.6 \mathrm{Mgha}^{-1}\right)$. We anticipated the lower stalk (i.e. high-cut bottom) would contribute a substantial amount of dry matter because of greater stalk thickness at the base of the plant. However, the high-cut top fraction produced more stover because cobs, the most dry matter dense component of stover, were part of that fraction.

The normal cut scenario provided about $76 \%$ of the stover achieved by the low cut, with far less risk of combine damage and much greater field efficiency because the ground speed was greater [30]. This scenario also collected about 5\% more stover than the high-cut top, with less risk of leaving grain in the field. In comparison to estimates by Graham et al. [6], our normal cut scenario collected only $0.07 \mathrm{Mg} \mathrm{ha}^{-1}$ less than their estimate, but the amount of residue left on the soil in our study $(\sim 24 \%)$ was less than their prediction $(\sim 32 \%)$. This may appear to be sufficient residue for surface cover, but the amount of $\mathrm{C}$ returned to the soil was only $25-30 \%$ of that suggested by Johnson et al. [28] as being needed to maintain soil organic matter.

The high-cut bottom fraction also had a very high water content $(\sim 64 \%)$ which would significantly increase transportation costs and require either extensive drying or storage under anaerobic (wet) conditions [31]. Biomass that needs to be collected with greater water content is generally more expensive to harvest, store, and transport than dry biomass. Mixing the very wet stover with the drier upper plant parts and cobs (i.e. low-cut scenario) resulted in intermediate water content for the low-cut scenario (Table 1). The relatively small mass and very high water content make the base of the stalk less desirable as an ethanol feedstock. This fraction would also likely incur dockage at a dilute acid biorefinery, because $60 \%$ water content is the cutoff point beyond which those operations will become more expensive due to dilution of the pretreatment catalytic agents such as sulfuric acid. The base of the stalk is also the stover fraction that has greatest potential for soil contamination due to raindrop splash and field operations during harvest. Our preliminary results suggest that leaving the stalk base in the field would be a wise choice from several perspectives.

\subsection{Stover mutrient removal}

Macro- $(\mathrm{N}, \mathrm{P}, \mathrm{K}, \mathrm{Ca}$, and $\mathrm{Mg})$ and micro-nutrient $(\mathrm{Cu}$, $\mathrm{Fe}, \mathrm{Mn}$, and $\mathrm{Zn}$ ) concentrations in the stover for the various harvest scenarios are presented in Table 2. The concentrations were consistent with other corn hybrids $[29,32]$ and when multiplied by the dry biomass revealed an additional $\mathrm{N}$-removal in the stover of 34 and $42 \mathrm{kgha}^{-1}$ for the high-cut top and normal cut harvest scenarios, respectively (Table 3 ). Phosphorus and $\mathrm{K}$ removed in the stover averaged 3.9 and $34 \mathrm{kgha}^{-1}$, respectively. The increased nutrient removal associated with harvesting crop residues for biofuels or other bio-products is a consideration that has a short-term economic impact and a potential long-term sustainability impact. For soils such as the Clarion-Nicollet-Webster association where this field study was conducted, one long-term effect could be an increased potassium deficiency [33], especially if no-till or other reduced tillage practices are used to minimize soil erosion because harvest of crop residue has reduced surface cover. The short-term impact is the additional fertilizer cost that may be incurred to replace the $\mathrm{N}, \mathrm{P}$, and $\mathrm{K}$ removed with the stover. Recent increases in the cost of natural gas used for fertilizer $\mathrm{N}$ production and increases in general transportation costs for all fertilizer materials have substantially increased the value of recycling plant nutrients from one crop to the next. For example, total replacement cost for the three macronutrients averaged

Table 2

Nutrient concentrations in corn stover collected using different harvest scenarios

\begin{tabular}{|c|c|c|c|c|c|c|c|c|c|c|}
\hline \multirow[t]{2}{*}{ Harvest scenario } & $\mathrm{C}$ & $N$ & $\mathbf{P}$ & $\mathbf{K}$ & $\mathrm{Ca}$ & $\mathrm{Mg}$ & $\mathrm{Cu}$ & $\mathrm{Fe}$ & $\mathrm{Mn}$ & $\mathrm{Zn}$ \\
\hline & \multicolumn{4}{|c|}{$\mathrm{mgg}^{-1}$} & \multicolumn{6}{|c|}{$\mu g \mathrm{~g}^{-1}$} \\
\hline High-cut top & 444 & 7.0 & 0.79 & 7.05 & 3.95 & 3.07 & 1.4 & 42 & 7 & 6 \\
\hline High-cut bottom & 440 & 8.1 & 0.57 & 19.62 & 4.05 & 3.83 & 0.8 & 86 & 8 & 4 \\
\hline Low cut & 444 & 7.0 & 0.62 & 6.52 & 3.70 & 3.74 & 1.1 & 63 & 6 & 4 \\
\hline Normal cut & 440 & 8.0 & 0.79 & 6.74 & 5.40 & 4.04 & 1.2 & 51 & 13 & 9 \\
\hline $\operatorname{LSD}(0.05)$ & ns & 0.6 & $\mathrm{Ns}$ & 5.58 & 0.87 & 0.25 & 0.2 & 12 & ns & ns \\
\hline
\end{tabular}


$\$ 54.41 \mathrm{ha}^{-1}$ for the high-cut top and normal cut harvest strategies. Collecting the bottom portion of the corn plant increased replacement cost to $\$ 67$ and $\$ 84 \mathrm{ha}^{-1}$ for the low cut and high-cut total (top plus bottom) scenarios, respectively. When calculated per metric ton $(\mathrm{Mg})$ of corn stover, the average nutrient replacement cost for the highcut top and normal cut scenarios was $\$ 10.93 \mathrm{Mg}^{-1}$. Including compensation for $\mathrm{Ca}, \mathrm{Mg}$, and four micronu- trients $(\mathrm{Cu}, \mathrm{Fe}, \mathrm{Mn}$, and $\mathrm{Zn})$ would increase these costs even further.

\subsection{Stover conversion}

The high-cut bottom scenario resulted in the greatest glucan concentration while the normal cut scenario produced the most xylans (Table 4 ). When converted to

Table 3

Nutrient removal associated with four corn stover harvest scenarios

\begin{tabular}{|c|c|c|c|c|c|c|c|c|c|c|}
\hline Harvest scenario & $\mathrm{C}$ & $\mathrm{N}$ & $\mathrm{P}$ & K & $\mathrm{Ca}$ & $\mathrm{Mg}$ & $\mathrm{Cu}$ & $\mathrm{Fe}$ & $\mathrm{Mn}$ & $Z_{n}$ \\
\hline & $\mathrm{Mgha}^{-1}$ & \multicolumn{5}{|c|}{$\mathrm{kgha}^{-1}$} & \multicolumn{4}{|c|}{$\mathrm{gha} \mathrm{a}^{-1}$} \\
\hline High-cut top & 2.16 & 34.3 & 3.8 & 34.2 & 19.2 & 14.9 & 7 & 202 & 35 & 28 \\
\hline High-cut bottom & 0.75 & 13.8 & 1.0 & 33.5 & 6.9 & 6.6 & 1 & 148 & 14 & 6 \\
\hline Low cut & 2.97 & 47.1 & 4.1 & 43.6 & 24.7 & 25.0 & 8 & 419 & 40 & 25 \\
\hline Normal cut & 2.24 & 42.0 & 4.0 & 34.3 & 27.5 & 20.6 & 6 & 258 & 64 & 46 \\
\hline $\operatorname{LSD}(0.05)$ & 0.07 & 2.9 & 1.8 & ns & 4.6 & 0.9 & 1 & 26 & ns & ns \\
\hline
\end{tabular}

Table 4

Chemical characterization of corn stover collected using four different harvest scenarios

\begin{tabular}{|c|c|c|c|c|c|c|c|c|c|c|}
\hline \multirow[t]{3}{*}{ Harvest scenario } & \multirow[t]{3}{*}{ EtOH solubles } & \multicolumn{8}{|c|}{ Water ext } & \multirow[t]{3}{*}{ Structural inorganics } \\
\hline & & \multirow[t]{2}{*}{ Sucrose } & Others & Glucan & Xylan & Galactan & Arabinan & Mannan & Lignin & \\
\hline & & & \multicolumn{7}{|l|}{$\mathrm{mgg}^{-1}$} & \\
\hline High-cut top & 46 & 13 & 42 & 337 & 212 & 15 & 29 & 10 & 134 & 0 \\
\hline High-cut bottom & 39 & 0 & 73 & 376 & 189 & 11 & 21 & 10 & 164 & 0 \\
\hline Low cut & 42 & 6 & 59 & 359 & 207 & 15 & 27 & 8 & 155 & 11 \\
\hline Normal cut & 45 & 0 & 24 & 339 & 215 & 14 & 30 & 11 & 127 & 0 \\
\hline \multirow[t]{2}{*}{ Harvest scenario } & \multirow[t]{2}{*}{$\begin{array}{l}\text { Extractable } \\
\text { inorganics }\end{array}$} & Protein & Acetyl & Uronic acid & $\begin{array}{l}\text { Total } \\
\text { solubles }\end{array}$ & $\begin{array}{l}\text { Total } \\
\text { structurals }\end{array}$ & Total & & $\mathrm{GH}^{\mathrm{a}}$ & $\mathrm{NH}^{\mathrm{b}}$ \\
\hline & & \multicolumn{8}{|l|}{$\mathrm{mgg}^{-1}$} & \\
\hline High-cut top & 21 & 36 & 29 & 36 & 129 & 883 & 1010 & & 0.711 & 0.207 \\
\hline High-cut bottom & 25 & 52 & 35 & 38 & 89 & 838 & 930 & & 3.58 & 1.48 \\
\hline Low cut & 27 & 45 & 34 & 38 & 127 & 844 & 970 & & 1.83 & 0.560 \\
\hline Normal cut & 25 & 41 & 25 & 33 & 128 & 865 & 990 & & 1.61 & 0.392 \\
\hline
\end{tabular}

${ }^{a} \mathrm{Global} H(\mathrm{GH})$ is a measure of the probability that a sample belongs to the calibration population set [X].

${ }^{b}$ Neighborhood $\mathrm{H}(\mathrm{NH})$ is a measure of how far the nearest calibration sample is from the measured sample. NH values over 0.6 will have higher error bars than the traditional error bars [X].

Table 5

Theoretical ethanol yields from corn stover collected using four different harvest scenarios

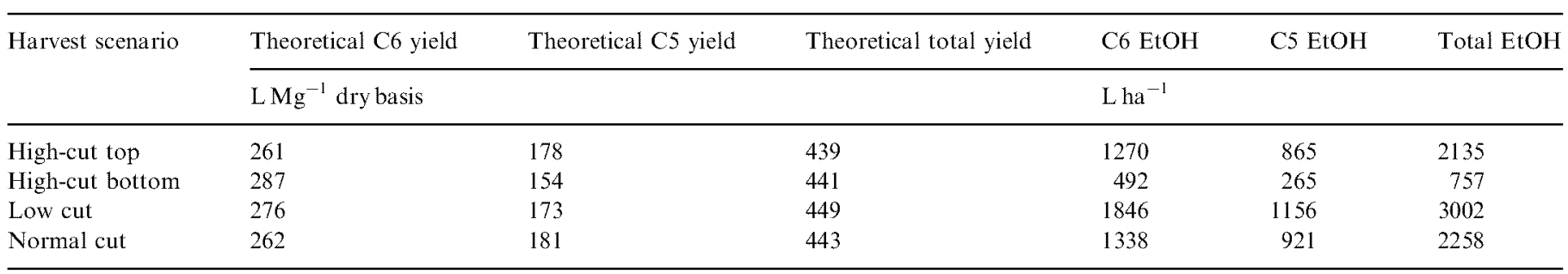


theoretical ethanol using the NREL calibration model for C6 fermentation [34] yields ranged from 492 to $1846 \mathrm{~L} \mathrm{ha}^{-1}$ (Table 5).

Stover samples from the four harvest scenarios were also compared using a reduced-severity dilute acid pretreatment followed by C6 SSF conversion to ethanol. This process showed significant differences in the polymer yields, particularly in the high-cut top stover samples (Table 6). Arabinan removal was also most complete in the high-cut top and normal cut samples.

Pretreated and native stover samples were also compared using the SSF procedure (Fig. 4). None of the native samples showed statistically different ethanol conversion after 7 days of SSF processing (Figs. 4 and 5) but with pretreatment, the high-cut top fraction produced significantly more ethanol than the high-cut bottom fraction. This outcome agrees with pretreatment results suggesting that the high-cut top stover harvest scenario may also result in lower biorefinery processing costs. These results also correlate well with other INL and University of Kentucky (UK) studies (unpublished data), and work at NREL [35].

The intensity of what is an "adequate" dilute-acid pretreatment varies significantly among the various anatomical fractions of corn stover. In the NREL study [35], it was found that the optimum pretreatment severity for cobs

Table 6

Sugars analyzed in the hydrolysate wash water from the reduced severity, dilute-acid pretreatment screening assay

\begin{tabular}{|c|c|c|c|c|c|c|}
\hline Harvest scenario & & Glucan & Xylan & Galactan & Arabinan & Mannan \\
\hline \multirow[t]{3}{*}{ High-cut top } & Hydrolysate sugars ${ }^{\mathrm{a}}$ & $4.0 \mathrm{~A}$ & $17.5 \mathrm{~A}$ & 0.4 & $3.0 \mathrm{~A}$ & 0.1 \\
\hline & Sd & 0.90 & 3.47 & 0.05 & 0.68 & 0.02 \\
\hline & Polymer removal ${ }^{b}$ & 12.0 & 82.8 & 27.7 & 101.0 & 15.0 \\
\hline \multirow[t]{3}{*}{ High-cut bottom } & Hydrolysate sugars & $1.8 \mathrm{C}$ & $10.8 \mathrm{~B}$ & 0.3 & $1.4 \mathrm{~B}$ & 0.1 \\
\hline & $\mathrm{Sd}$ & 0.17 & 1.02 & 0.02 & 0.11 & 0.01 \\
\hline & Polymer removal & 4.9 & 57.3 & 22.5 & 65.8 & 10.8 \\
\hline \multirow[t]{3}{*}{ Low cut } & Hydrolysate sugars & $2.6 \mathrm{BC}$ & $13.9 \mathrm{AB}$ & 0.4 & $2.2 \mathrm{~A}$ & 0.1 \\
\hline & $\mathrm{Sd}$ & 0.17 & 1.02 & 0.02 & 0.11 & 0.01 \\
\hline & Polymer removal & 7.1 & 67.3 & 27.5 & 81.3 & 12.3 \\
\hline \multirow[t]{3}{*}{ Normal cut } & Hydrolysate sugars & $3.0 \mathrm{~B}$ & $14.3 \mathrm{AB}$ & 0.4 & $2.3 \mathrm{~A}$ & 0.1 \\
\hline & $\mathrm{Sd}$ & 0.23 & 1.22 & 0.05 & 0.19 & 0.00 \\
\hline & Polymer removal & 8.8 & 66.4 & 27.1 & 77.7 & 9.6 \\
\hline \multirow[t]{3}{*}{ NREL 34M95 (control biomass) } & Hydrolysate sugars & $4.0 \mathrm{~A}$ & $14.6 \mathrm{AB}$ & 0.5 & $2.6 \mathrm{~A}$ & 0.2 \\
\hline & Sd & 0.34 & 1.47 & 0.04 & 0.23 & 0.02 \\
\hline & Polymer removal & 11.9 & 64.4 & 41.8 & 99.5 & 28.9 \\
\hline
\end{tabular}

Data are means of quadruplicate samples; identical letters within a column denote no significance was found using a one-way ANOVA followed by Tukey-Kramer HSD at an alpha of 0.05 using JMP statistical software (SAS Institute Inc., Cary, NC).

${ }^{a}$ Hydrolysate sugars units: (polymer wt/total wt) $\times 100-\%$ total wt.

${ }^{b}$ Polymer removal units: (wt polymer removed/wt original polymer) $\times 100-\%$ original polymer wt.
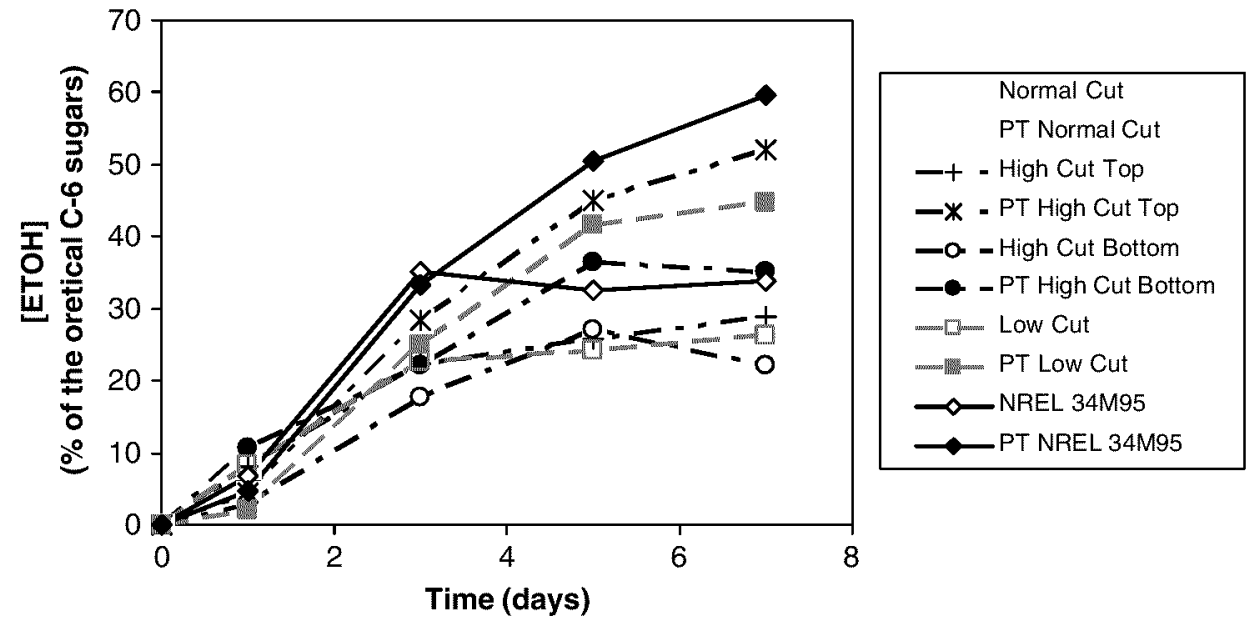

Fig. 4. Time courses of the means of quadruplicate samples processed with and without a reduced severity dilute acid pretreatment then run for ethanol SSF. 
and husks was much less than for the stalk fractions (node, internode, and rind). Those results may be relevant to this study because the proportion of cobs and husks was greater in the high-cut top stover fraction and lowest (i.e. none) in the high-cut bottom fraction of stover. This suggests that the high-cut top fraction in our study may have more efficient processing due to the partial anatomical fractionation. Normal cut theoretical ethanol yield from C6 sugars was not different from that of the high-cut top, supporting the proposal that the normal cut scenario may optimize harvest convenience and speed, soil erosion and quality protection, and ethanol yield.

Correlations between theoretical ethanol yield and several ethanol and dry matter yield characteristics are presented in Table 7. We found no relationship between total and theoretical ethanol yield per unit of dry mass $(r<0.950$, the critical $r)$. However, when the correlation between ethanol yield per unit land area was computed, a strong correlation was found between total ethanol yield and amount of ethanol from both the C6 $(r=0.9986)$ and C5 $(r=0.9964)$ sugars. The strongest correlation was found between total ethanol yield and stover yield ( $r=0.9997)$, suggesting that among the harvest scenarios, stover yield plays a greater role in determining ethanol

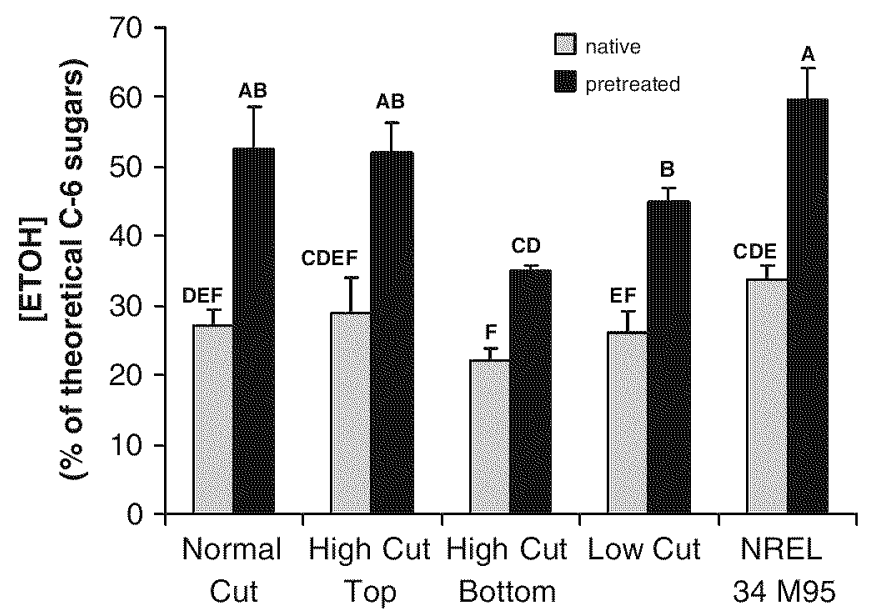

Fig. 5. Day 7 statistics for ethanol-SSF of pretreated and native com stover. Data are means of quadruplicate samples and error bars represent one standard deviation; identical letters within a column denote no significance was found using a one-way ANOVA followed by TukeyKramer HSD at an alpha of 0.05 using JMP statistical software (SAS Institute Inc., Cary, NC). yield than the amount of ethanol produced per unit dry matter.

\subsection{Thermochemical conversion of stover}

A thermochemical conversion study of the residue collected by the different harvest scenarios showed that percent moisture (Table 1) had the largest effect on gasification parameters and was the major discriminator among the four harvest scenarios when evaluated as a potential feedstock. Beyond moisture, the most notable result was that the ash fusion temperature of the high-cut top stover was markedly lower than for stover from the other harvest scenarios (Table 8). This difference would probably not require major gasification system design changes other than perhaps the use of a fluidized bed reactor to avoid hot pockets, as optimal temperatures for gasification of this material reportedly fall between 900 and $1000{ }^{\circ} \mathrm{C}$ [36]. Other differences and trends in the gasification parameters are likely not significant, and several observations violate rules of mixtures. For example, constituent concentrations found in the ultimate analysis of low cut stover should fall within the range between the high-cut top and the high-cut bottom stover. In practice several of the constituent concentrations of the low cut material fell outside of this range, including $\mathrm{SiO}_{2}, \mathrm{CaO}$, $\mathrm{K}_{2} \mathrm{O}$, and $\mathrm{Cl}$. However, those differences were typically quite small and point to feedstock variability more than operational errors.

Comparable thermochemical conversion (Table 8) and nutrient concentration (Table 2) data showed a low but positive correlation confirming similar trends in residue samples from the four harvest scenarios. For example, total C concentrations ranged from 440 to $444 \mathrm{mgg}^{-1}$ when measured by dry combustion (Table 2), while the ultimate analysis showed a range of $469-472 \mathrm{mg} \mathrm{g}^{-1}$ (Table 9). This small difference $(2.6-3.2 \%)$ provides confidence in the estimates of carbon concentrations in the four corn stover samples. Many of the other elements showed similar trends for both methods. The most likely cause for the differences was volatilization due to the high temperature during the ashing process.

\section{Conclusions}

To be acceptable to producers, the harvest scenario for stover collection must not adversely affect grain harvest.

Table 7

Simple correlation $(r)$ between theoretical total ethanol yield and several theoretical ethanol and stover yield characteristics across harvest scenarios

\begin{tabular}{lllllll}
\hline & Stover yield & Theoretical C6 yield & Theoretical C5 yield & Theoretical total yield & C6 EtOH & C5 EtOH \\
\hline Total EtoH & 0.9997 & -0.5332 & 0.7758 & 0.6245 & 0.9986 & 0.9964 \\
Significance $^{*}$ & $* *$ & $\mathrm{~ns}$ & $\mathrm{~ns}$ & $\mathrm{~ns}$ & $* *$ & $* *$ \\
\hline
\end{tabular}

**, significant at $\alpha=0.01$.

${ }^{a} \mathrm{n} s$, not significant. 
Table 8

Thermochemical conversion data for corn stover from the four harvest scenarios

\begin{tabular}{|c|c|c|c|c|}
\hline & High-cut top & High-cut bottom & Low cut & Normal cut \\
\hline Proximate & $\operatorname{mgg}^{-1}$ & & & \\
\hline Ash & 46 & 57 & 47 & 57 \\
\hline volatile & 781 & 766 & 789 & 779 \\
\hline fixed $\mathrm{C}$ & 173 & 177 & 164 & 164 \\
\hline Total & 1000 & 1000 & 1000 & 1000 \\
\hline Ultimate & $\operatorname{mg} g^{-1}$ & & & \\
\hline Carbon & 472 & 469 & 472 & 470 \\
\hline Hydrogen & 57 & 56 & 57 & 58 \\
\hline Nitrogen & 6 & 6 & 5 & 6 \\
\hline Sulfur & 1 & 0 & 1 & 1 \\
\hline $\mathrm{Ash}$ & 46 & 57 & 47 & 57 \\
\hline Oxygen & 420 & 412 & 418 & 409 \\
\hline Chlorine $^{\mathrm{a}}$ & 2 & 3 & 2 & 3 \\
\hline Total & 1000 & 1000 & 1000 & 1000 \\
\hline $\mathrm{C} / \mathrm{H}$ ratio & 8.3 & 8.4 & 8.3 & 8.2 \\
\hline Elements in Ash & $\mathrm{mgg}^{-1}$ & & & \\
\hline $\mathrm{SiO}_{2}$ & 448 & 404 & 522 & 513 \\
\hline $\mathrm{AL}_{2} \mathrm{O}_{3}$ & 1 & 21 & 1 & 1 \\
\hline $\mathrm{TiO}_{2}$ & 1 & 1 & 1 & 1 \\
\hline $\mathrm{FE}_{3} \mathrm{O}_{3}$ & 5 & 7 & 6 & 6 \\
\hline $\mathrm{CaO}$ & 93 & 110 & 112 & 99 \\
\hline $\mathrm{MgO}$ & 65 & 126 & 97 & 84 \\
\hline $\mathrm{Na}_{2} \mathrm{O}$ & 24 & 10 & 12 & 9 \\
\hline $\mathrm{K}_{2} \mathrm{O}$ & 193 & 198 & 138 & 138 \\
\hline $\mathrm{P}_{2} \mathrm{O}_{5}$ & 69 & 28 & 54 & 55 \\
\hline $\mathrm{SO}_{3}$ & 15 & 12 & 13 & 12 \\
\hline $\mathrm{Cl}$ & 31 & 36 & 26 & 27 \\
\hline $\mathrm{CO}_{2}$ & 5 & 12 & 6 & 7 \\
\hline $\mathrm{SiO}_{2} / \mathrm{K}_{2} \mathrm{O}$ ratio & 2.3 & 2.0 & 3.8 & 3.7 \\
\hline Ash fusion temp & $\mathrm{C}$ & & & \\
\hline Oxidizing atm & & & & \\
\hline Initial & 984 & 1166 & 1140 & 1141 \\
\hline Softening & 1032 & 1173 & 1168 & 1175 \\
\hline Hemispherical & 1108 & 1178 & 1188 & 1192 \\
\hline Fluid & 1142 & 1184 & 1192 & 1204 \\
\hline Reducing atm & ${ }^{\circ} \mathrm{C}$ & & & \\
\hline Initial & 998 & 1038 & 1070 & 1090 \\
\hline Softening & 1021 & 1118 & 1189 & 1176 \\
\hline Hemispherical & 1092 & 1132 & 1201 & 1186 \\
\hline Fluid & 1117 & 1149 & 1226 & 1193 \\
\hline \multicolumn{5}{|c|}{ Energy parameters (dry basis) } \\
\hline HHV $\left(\mathrm{kJ} \mathrm{g}^{-1}\right)$ & 18.3 & 18.3 & 18.2 & 18.3 \\
\hline $\operatorname{MMF}\left(\mathrm{kJ} \mathrm{g}^{-1}\right)$ & 19.2 & 19.5 & 19.2 & 19.4 \\
\hline $\operatorname{MAF}\left(\mathrm{kJ} \mathrm{g}^{-1}\right)$ & 19.2 & 19.4 & 19.1 & 19.4 \\
\hline $\mathrm{kg}$ alkali $\left(\mathrm{GJ}^{-1}\right)$ & 0.6 & 0.7 & 0.4 & 0.5 \\
\hline $\mathrm{kg} \operatorname{ash}\left(\mathrm{GJ}^{-1}\right)$ & 2.8 & 3.5 & 2.9 & 3.5 \\
\hline $\operatorname{kg} \mathrm{SO}_{2}\left(\mathrm{GJ}^{-1}\right)$ & 0.1 & 0.1 & 0.1 & 0.1 \\
\hline $\operatorname{DSCF}\left(\mathrm{GJ}^{-1}\right)$ & 9959 & 9899 & 10040 & 10041 \\
\hline
\end{tabular}

${ }^{a}$ Chlorine is not usually reported as part of the ultimate analysis.

Our one-pass harvest system is a prototype and does not exist in the marketplace. Therefore, it must be assumed that the normal cut scenario would be most acceptable because the others would slow ground speed and harvest efficiency. The preliminary results reported here indicate harvesting at the normal height would probably provide the amount of crop residue projected from long-term yield records and typical harvest indices, although the amount of residue left on the soil surface may be less than expected. The macro-nutrient replacement value for the normal harvest scenario under our conditions was $\$ 57.36 \mathrm{ha}^{-1}$ or $\$ 11.27 \mathrm{Mg}^{-1}$. Harvesting the lower portion of the stalk 
would add very little dry matter, slow harvest efficiency, increase nutrient replacement costs, and decrease surface cover and protection from wind and water erosion. Harvesting the bottom portion of the stalks would also produce a feedstock with excessive water content that would increase transportation and storage costs, result in minimal improvement on theoretical ethanol yield, and may create contamination problems in the biorefinery.

\section{Acknowledgements}

The INL work was supported by the U.S. Department of Energy, Office of Energy Efficiency and Renewable Energy, under DOE Idaho Operations Office Contract DE-AC07-05ID14517. The Iowa State University work was partially supported by the U.S. Department of Energy under Cooperative Agreement No. DE-PS07-01ID14039 and by the U.S. Department of Agriculture/U.S. Department of Energy program under grant number NRCS 683A75-4-137. We thank Larry Pellack and Jay Berkey for their assistance in determining water and nutrient content of the crop residues, Debby Bruhn and Cynthia Breckenridge for pretreatment and SSF screening, and John Scahill of the DOE Golden Field Office and Richard Boardman of INL for assistance in interpreting gasification results.

\section{References}

[1] USDOE. Vision for bioenergy \& biobased products in the United States. [Online]. Available at <http://www.biomass.govtools.us/pdfs/ BioVision_03_Web.pdf $>2002$ (verified June 2006).

[2] USDOE. Biomass Program Multiyear Technical Plan [Online]. Available at <http://www.biomass.govtools.us/pdfs/MYTP\%20FY\% $202002 \% 20 \mathrm{v} 13$.pdf $>2003$ (verified June 2006).

[3] IOGEN Corporation. Cellulose ethanol [Online]. Available at $\langle$ http://www.iogen.ca/cellulose_ethanol/what_is_ethanol/cellulose_ ethanol.pdf $\rangle .2005$ (verified June 2006).

[4] USDOE. Roadmap for agriculture biomass feedstock supply in the United States [Online]. Available at 〈http://devafdc.nrel.gov/pdfs/ 8245.pdf $>2003$ (verified June 2006).

[5] USDOE. Multi year program plan, 2007-2012 [Online]. Available at 〈http://wwwl.eere.energy.gov/biomass/pdfs/mypp.pdf) 2005 (verified June 2006).

[6] Graham RL, Nelson R, Sheehan J, Perlack RD, Wright LL. Current and potential U.S. corn stover supplies. Agronomy Journal 2006; $99(1)$, in press.

[7] Hanway JJ. Growth stages of corn (Zea mays L.). Agronomy Journal $1963 ; 55: 487-92$.

[8] Pordesimo LO, Edens WC, Sokhansanj S. Distribution of aboveground biomass in corn stover. Biomass and Bioenergy 2004;26: 337-43.

[9] Crofcheck CL, Montross MD. Effect of stover fraction on glucose production using enzymatic hydrolysis. Transactions American Society of the Agricultural Engineers 2004;47:841-4.

[10] Nelson RG. Resource assessment and removal analysis for corn stover and wheat straw in the Eastern and Midwestern United States-rainfall and wind-induced soil erosion methodology. Biomass and Bioenergy 2002;22:349-63.

[11] Larson WE. Crop residue: energy production or erosion control? Journal of Soil and Water Conservation 1979;34:74-6.
[12] Lindstrom MJ, Gupta SC, Onstad CA, Larson WE, Holt RF. Tillage and crop residue effects on soil erosion in the Corn Belt. Journal of Soil and Water Conservation 1979;34:80-2.

[13] Maskina MS, Power JF, Doran JW, Wilhelm WW. Residual effects on no-till crop residues on corn yield and nitrogen uptake. Soil Science Society of America Journal 1993;57:1555-60.

[14] Clapp CE, Allmaras RR, Layese MF, Linden DL, Dowdy RH. Soil organic carbon and $13 \mathrm{C}$ abundance as related to tillage, crop residue, and nitrogen fertilization under continuous corn management in Minnesota. Soil and Tillage Research 2000;55:127-42.

[15] Wilhelm WW, Doran JW, Power JF. Corn and soybean yield response to crop residue management under no-tillage production systems. Agronomy Journal 1986;78:184 9.

[16] Wilhelm WW, Johnson JM-F, Hatfield JL, Voorhees WB, Linden DR. Crop and soil productivity response to corn residue removal: a literature review. Agronomy Journal 2004;96:1-17.

[17] Wilts AR, Reicosky DC, Allmaras RR, Clapp CE. Long-term corn residue effects: harvest alternatives, soil carbon turnover, and rootderived carbon. Soil Sciences Society of America Journal 2004; $68: 1342-51$

[18] Kim S, Dale BE. Life cycle assessment of various cropping systems utilized for producing biofuels: bioethanol and biodiesel. Biomass and Bioenergy 2005;29:426-39.

[19] Mills HA, Jones Jr JB. Plant analysis handbook II. Athens, GA: MicroMacro Publishing; 1996.

[20] Hames BR, Thomas SR, Sluiter AD, Roth CJ, Templeton DW. Rapid biomass analysis - new tools for compositional analysis of corn stover feedstocks and process intermediates from ethanol production. Applied Biochemistry and Biotechnology 2003;105:5-16.

[21] Thompson DN, Houghton TP, Lacey JA, Shaw PG, Hess JR. Preliminary investigation of fungal bioprocessing of wheat straw for production of straw-thermoplastic composites. Applied Biochemistry and Biotechnology 2003;105/108:423-36.

[22] Weimer PJ, Dien BS, Springer TL, Vogel KP. In vitro gas production as a surrogate measure of the fermentability of cellulosic biomass to ethanol. Applied Microbiology and Biotechnology 2005;67(1):52-8.

[23] Dowe N, McMillan J. NREL Biofuels Program Laboratory Analytical Procedure LAP-008. SSF Experimental Protocols: Lignocellulosic Biomass Hydrolysis and Fermentation. Available at $\langle$ http://devafdc.nrel.gov/pdfs/4691.pdf〉 2001 (verified June 2006).

[24] NASS. USDA National Agricultural Statistics Service Quick Stats, Iowa County Data - Crops [Online]. Available at $\langle$ http://www.nass. usda.gov/index.asp\#top $>2005$ (verified June 2006).

[25] Prihar SS, Stewart BA. Using upper-bound slope through origin to estimate genetic harvest index. Agronomy Journal 1990;82:1160-5.

[26] Linden DL, Clapp CE, Dowdy RH. Long-term corn grain and stover yields as a function of tillage and residue removal in east central Minnesota. Soil and Tillage Research 2000;56:167-74.

[27] Tollenaar M. Genetic improvement in grain yield of commercial maize hybrids grown in Ontario from 1959 to 1988. Crop Science 1989;29:1365-71.

[28] Johnson JM-F, Allmaras RR, Reicosky DC. Estimating source carbon from crop residues, roots and rhizodeposits using the national grain-yield database. Agronomy Journal 2006;98:622-36.

[29] Larson WE, Holt RF, Carlson CW. Residues for soil conservation. In: Oschwald WR, editor. Crop residue management systems. ASA Spec. Publ. No. 31. Madison, WI: American Society of Agronomy, Inc; 1978. p. 1-15.

[30] Shinners KJ, Adsit GS, Binversie BN, Digman MF, Muck RE, Weimer PJ. Characteristic performance and yields using a single-pass, split-stream maize grain and stover harvester. Meeting Paper No. 05-6051. American Society of Agricultural Engineers, St. Joseph, MI, USA, 2005.

[31] Shinners KJ, Binversie BN, Savoie P. Harvest and storage of wet and dry corn stover as a biomass feedstock. Meeting Paper No. 03-6088. American Society of Agricultural Engineers, St. Joseph, MI, USA. 2003. 
[32] Aldrich SA, Scott WO, Hoeft RG. Modern Corn Production. Champaign, IL: A\&L Publications; 1986.

[33] Karlen DL, Kovar JL. Is $\mathrm{K}$ the Cinderella nutrient for reduced tillage systems? Fluid Journal 2005;13(4):8-11.

[34] USDOE. Theoretical ethanol yield calculator [Online]. Available at 〈http://wwwl.eere.energy.gov/biomass/ethanol_yield_calculator. $\mathrm{html}\rangle 2006$ (verified June 2006).
[35] Johnson DK, Davis MF, Ishizawa C, Templeton D. The dilute acid pretreatment of corn stover anatomical fractions. 27 th symposium on biotechnology for fuels and Chemicals. May 1-4, Denver, CO, 2005.

[36] Higman C, Burgt M. Gasification. ISBN 0-7506-7707-4 Burlington, MA: Gulf Professional Publishing, Elsevier Science. 2003. 